\title{
Increase the Strenght of Base and Subbase of Flexible Pavement by Adding Fledspar as Additive Material
}

\author{
Gatot Rusbintardjo $^{1 *}$, Lisa Fitriyana ${ }^{1}$, Nur Izzi M. Yusoff ${ }^{2}$, and Arafat Suleiman Yero ${ }^{3}$ \\ ${ }^{1}$ Department of Civil Engineering, Faculty of Engineering, Sultan Agung Islamic University \\ (UNISSULA), Semarang, Indonesia \\ ${ }^{2}$ Department of Civil and Structural Engineering, University Kebangsaan Malaysia - Malaysia \\ ${ }^{3}$ Department of Civil Engineering Abubakar TafawaBalewa University - Bauchi, Nigeria \\ *Corresponding Author: gatot.r@unissula.ac.id.
}

(Received: September $14^{\text {th }}, 2019$; Accepted: October $\left.21^{\text {st }}, 2019\right)$

\begin{abstract}
The strength and durability of the flexible pavement is highly dependent on the quality of the aggregate material used for base and subbase layers. This is can be understand since 95 percent of the weight-volume of the base and subbase layer is aggregate. Therefore using a good quality and strong base and subbase material is very important. In this paper, which is a report of a reseacrh, Feldspar is used as stabilizer of base and subbase materlias of flexible pavement. Feldspar is a group rock-ftant forming tectosilicate minerals that made up about $41 \%$ of the earth's continental crust by weight. 5 to $25 \%$ of Feldspar with increment of $5 \%$ by weight of the base and also subbase were added. Direct Shear and California Baring Ratio (CBR) test were conducted., beside water content and dry density test. The results of direct shear test show that cohesion of base and subbase materials decrease from $0,164 \mathrm{~kg} / \mathrm{cm}^{2}$ of original base and subbase materials become $0,01 \mathrm{~kg} / \mathrm{cm}^{2}$ for base and subbase material after adding with $25 \%$ of Feldspar, and angle of inernal friction increase from $47,67^{\circ}$ become $49,80^{\circ}$. Meanwhile the results of CBR test show that CBR value of base increase from $30 \%$ to $86,40 \%$, as well as for subbase increase from $21,50 \%$ to $87,30 \%$ after adding with $15 \%$ of Feldspar. It can be concluded that adding aggregate of base and subbase with Feldspar the strenght improve signicantly, and the influence is the strengthening of the base and subbase layers.
\end{abstract}

Keywords: Base and Subbase materials; Feldspar; Imporove; Quality and Strenght; Stabilize

\section{Introduction}

Flexible pavement usually consist of three layers which cover surface layer or wearing course layer at the top of the pavement, base layer which is placed directly under surface layer, and subbase layer which is placed under base layer and above the subgrade or road bed soil layer, as shown in Fig. 1.1.

In most asphalt pavements, the stiffness in each layer or lift is greater than that in the layer below and less than that in the layer above. This could be understood from the load distribution Fig. 1.2. where the stress at the surface layer is higher than that of the layer below. Therefore, the material used for the base and subbase must be durable aggregate and meet the spesification. According to [2], granular subbase material shall have a 4-day soaked CBR of not less than $30 \%$ when compacted at $100 \%$ of modified proctor AASHTO (T 180-D) and tested in accordance with AASHTO T 193, while base material must be crushed aggregate which shall have a 4-day soaked CBR of not less than $80 \%$ when compacted at $100 \%$ of modified proctor AASHTO (T180-D) and tested in accordance with AASHTO T 193. 


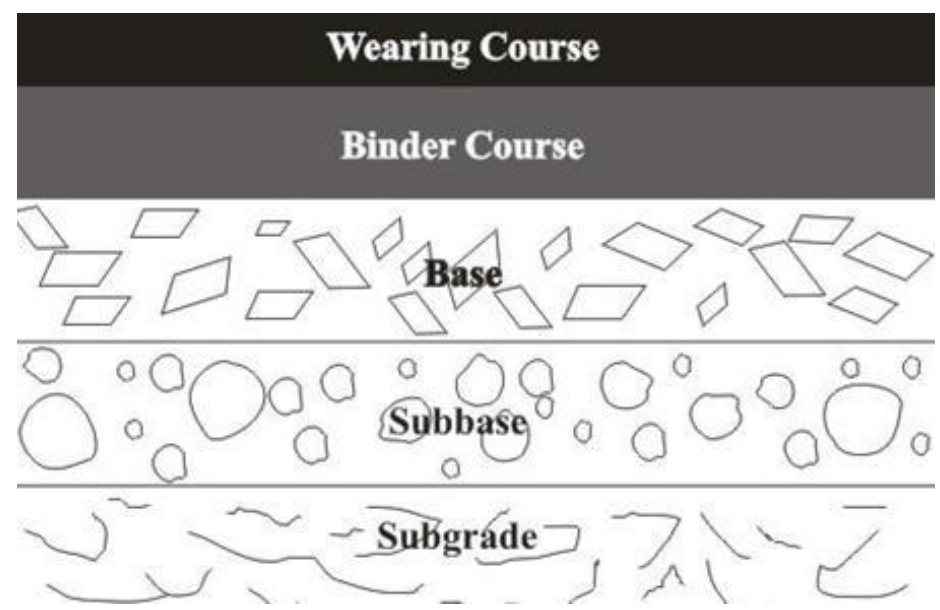

Fig. 1.1. Basic Flexible Pavement Structure (Source [1])

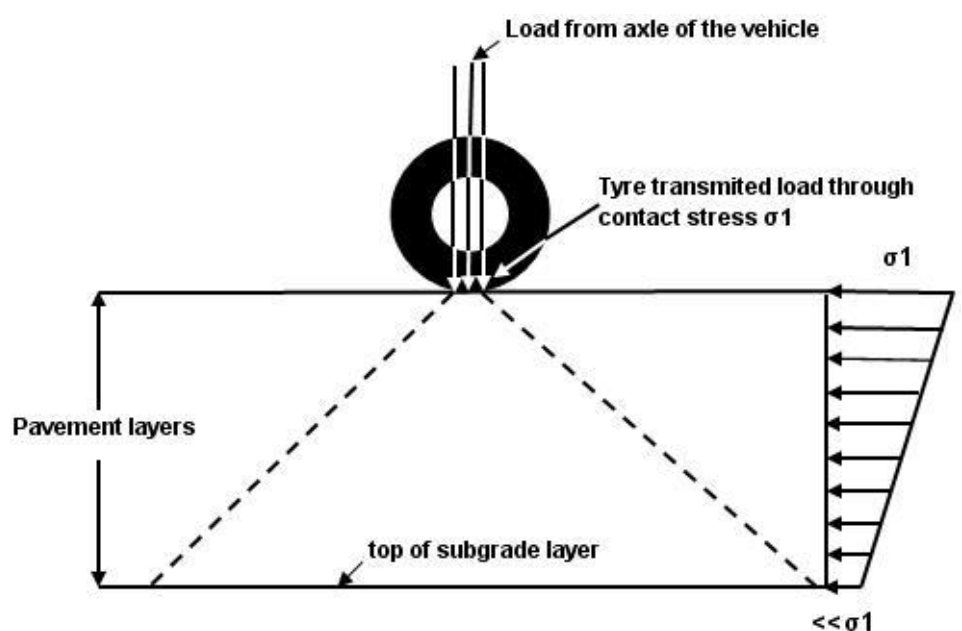

Fig. 1.2. Load distributions on flexible pavement (Source [1])

To get materials that can meet the specifications above, stabiliztion is performed using Feldspar on the existing aggregate base and subbase.

\section{Research Methodology}

This research was conducted in the Soil Mechanic Laboratory, Faculty of Engineering, Universitas Islam Sultan Agung (UNISSULA) of Semarang, Indonesia. Base and subbase materials was crushed stone obtained from Contractor's Base Camp located in Mangkang km10.00 of West Semarang.

Firstly some tests are carried out to determine the properties of the original aggregate of base and subbase, those tests were, determination of water content and dry density, CBR, and Dierct Shear tests. The original properties of aggregate base and subbase are given in Table 2.1. Secondly preparing Felsdpar which will be used as a stabilizing material. Feldspar is $\left(\mathrm{KAlSi}_{3} \mathrm{O}_{8}-\right.$ $\mathrm{NaAlSi}_{3} \mathrm{O}_{8}-\mathrm{CaAl}_{2} \mathrm{Si}_{2} \mathrm{O}_{8}$ ) are a group of rock-forming tectosilicate minerals that make up about $41 \%$ of the Earth's continental crust by weight. Feldspars crystallize from magma as veins in both intrusive and extrusive igneous rocks and are also present in many types of metamorphic rock [3]. Images of Feldspar are shown in Fig. 2.1 and Fig. 2.2. respectively [3]. Use as additive of aggregate base and subbase, the rocks of Feldspar was crushed into fine grains that pass sieve \# 
100 or into fine particles of $0.15 \mathrm{~mm}$ in diameter. So that it is obtained uniform particle of Feldspar with diameter $0.15 \mathrm{~mm}$.

Table 2.1. Properties of the original base and subbase

\begin{tabular}{lcc}
\hline \multicolumn{1}{c}{ Properties } & Base & Subbase \\
\hline Water content $(\%)$ & 5.458 & 3.874 \\
\hline Dry Density $\left(\mathrm{kg} / \mathrm{cm}^{3}\right)$ & 0.616 & 0.675 \\
\hline CBR $(\%)$ & 21.5 & 30 \\
\hline Cohesion $\left(\mathrm{kg} / \mathrm{cm}^{3}\right)$ & 0.164 & 0.164 \\
\hline Angle of Internal friction $\left(^{\circ}\right)$ & 47.67 & 47.47 \\
\hline Specific gravity & 1.682 & 1.682 \\
\hline
\end{tabular}

This reseach was conducted by two students of Department of Civil Engineering, Faculty of Engineerign UNISSULA as their Final Assigment to reach thier Bachelor Degree in Civil Engineering and supervise by lectures who are competent in the field of geotechnics engineering. Due of the time constraints, only three percentage of fine-Feldspar was added to the aggregate of base and subbase. The three percentages of Feldspar are 5, 10, and 15\% by weight of base or subbase. However, if the results do not reach the expaected specifications, then the percentage of Feldspar will be added.

The researh then continued with the CBR value and Direct Shear tests. Prior to those tests, activilty to find the optimum moisture content and dry density of each feldspar-base/subbase mixtures.

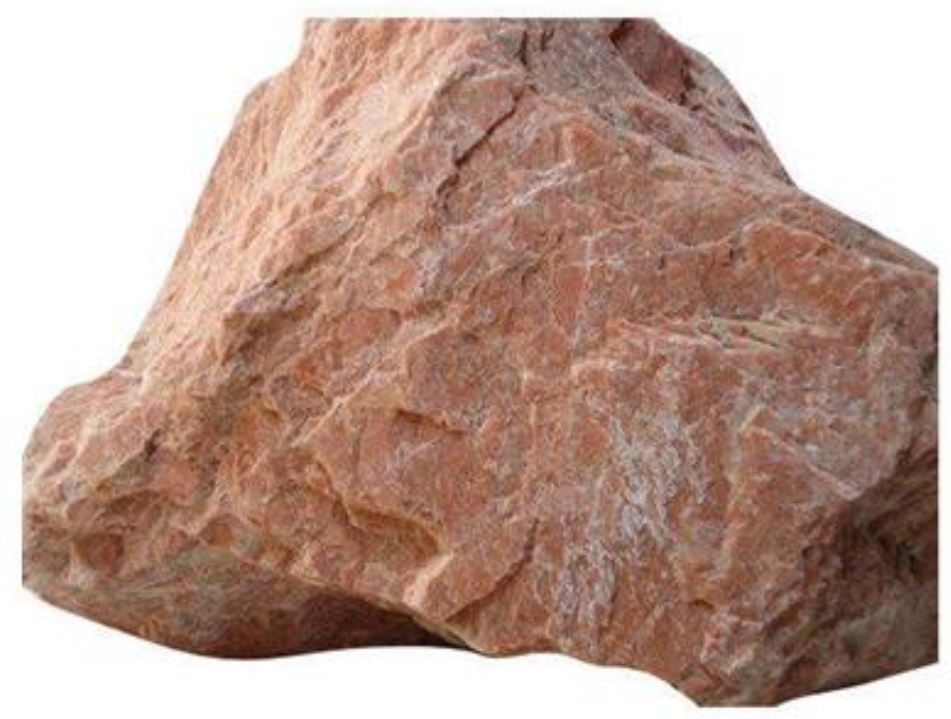

Fig. 2.1. Rock of Feldspar 


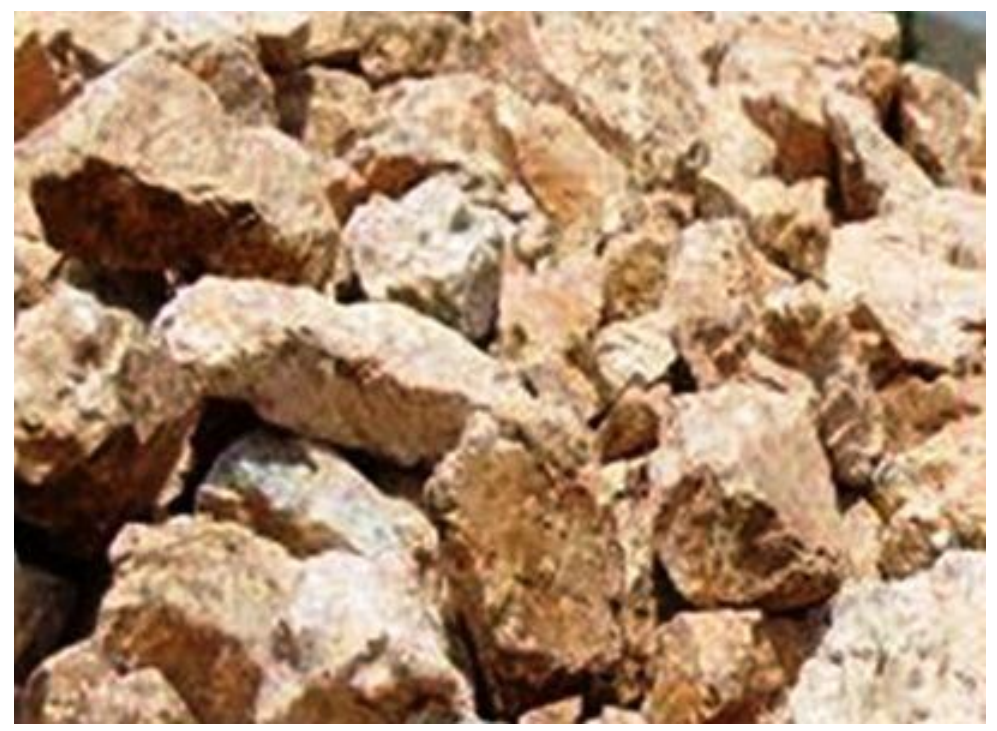

Fig. 2.2. Collction of Feldspar rocks.

\section{Results and Discussion}

\subsection{Water content and dry density}

Water content and Dry Density of original base and subbase and fledspar-base/subbase mixtures are shown in Table 3.1. It appeares that the water content as well as dry density increases with increasing of feldspar content in the aggregate of base amd subbase.

Table 3.1. Water content optimum and dry density of original base/subbase and fledspar-base/subbase mixtures

\begin{tabular}{ccccc}
\hline $\begin{array}{c}\text { Aggregate } \\
\text { Base/Subbase } \\
+\% \text { of Feldspar }\end{array}$ & \multicolumn{2}{c}{$\begin{array}{c}\text { Water Content } \\
(\boldsymbol{\%})\end{array}$} & \multicolumn{2}{c}{$\begin{array}{c}\text { Dry Density } \\
\left(\mathbf{k g} / \mathbf{c m}^{\mathbf{3}}\right)\end{array}$} \\
\hline 0 & Base & Subbase & Base & Subbase \\
\hline 5 & 5.458 & 3.874 & 0.616 & 0.675 \\
\hline 10 & 6.061 & 6.344 & 0.661 & 0.683 \\
\hline 15 & 7.143 & 7.706 & 0.680 & 0.710 \\
\hline & 8.202 & 9.589 & 0.696 & 0.749 \\
\hline
\end{tabular}

\subsection{California Bearing Ratio (CBR)}

The results of CBR test of original base and subbase and fledspar-base/subbase mixtures are shown in Table 3.2. and presented in the regression model in Fig. 3.1. The result shows that by adding Fedlspar to the base and subbase will result in a higher the CBR value. For aggregate base, by adding $15 \%$ Feldspar CBR value reach $86,40 \%$, while for subbase by adding $10 \%$ Feldspar CBR value reach $60,40 \%$. Regression model of base-Feldspar mixtures gives coefficient of determination, $\mathrm{R}$-square $=0.9610$ and coefficient of correlation, $\mathrm{R}=0.9805$, and for subbaseFeldspar mixtures gives coefficient of determination, R-square $=0,9890$ and coefficient of correlation, $\mathrm{R}=0.9945$ shows that between Feldspar content and CBR there is a strong correlation, where the contribution of Feldspar to CBR value is above $90 \%$. It is seen that the CBR value of the Feldspar soil is in accordance with the hypothesis. To reach specification for base material where $\mathrm{CBR}$ value $=90 \%$, Feldspar content must be $16.90 \%$ or $17 \%$. 
Table 3.2. CBR Value of original base/subbase and fledspar-base/subbase mixtures

\begin{tabular}{ccc}
\hline $\begin{array}{c}\text { Aggregate Base/Subbase }+ \\
\text { \% of Feldspar }\end{array}$ & \multicolumn{2}{c}{ CBR Value (\%) } \\
\hline 0 & Base & Subbase \\
\hline 5 & 30.00 & 21.50 \\
\hline 10 & 39.00 & 45.60 \\
\hline 15 & 60.60 & 60.40 \\
\hline & 86.40 & 87.30 \\
\hline
\end{tabular}
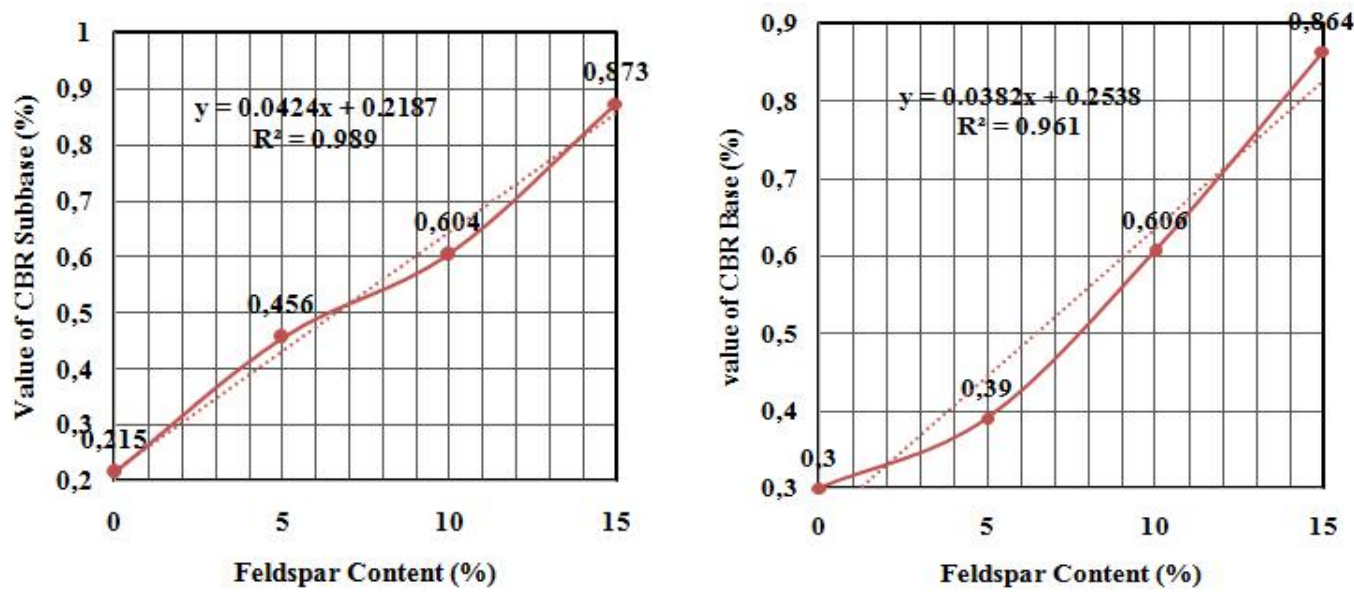

Fig. 3.1. Regression model of CBR Value of Base/Subbase+Feldpar mixtures

\subsection{Direct shear test}

Direct shar test results consist of cohesion value 'c' and angle of internal friction ' $\varphi$ ' are given in Table 3.3. Regression model of Cohesion value $\mathrm{c}$ and angle of internal friction $\varphi$ of aggregate base and subbase are given in Fig 3.2. The result shows that by adding Fedlspar to the base and subbase cohesion of aggregate base and subbase decrease become almost zero, and angle of internal friction $\varphi$ littel bid increase from $47,67^{\circ}$ to $48,85^{\circ}$. Regression model of cohesion value of base/subbase-Feldspar mixtures gives coefficient of determination, R-square $=0.9310$ and coefficient of correlation, $\mathrm{R}=0.9650$, and for angle of internal friction $\varphi$ subbase-Feldspar mixtures coefficient of determination, $\mathrm{R}$-square $=0.9280$ and coefficient of correlation, $\mathrm{R}=$ 0.9633 .

Table 3.3. Direct Shear test results of aggregate bas and subbase

\begin{tabular}{ccc}
\hline $\begin{array}{c}\text { Aggregate } \\
\text { Base/Subbase }+ \\
\% \text { of Feldspar }\end{array}$ & \multicolumn{2}{c}{$\begin{array}{c}\text { Direct Shear test result } \\
\text { of base and subbase }\end{array}$} \\
\cline { 2 - 3 } Cohesion $(\mathbf{c )}$ & $\begin{array}{c}\text { Angle of internal } \\
\text { Friction }(\boldsymbol{\varphi})\end{array}$ \\
\hline 0 & 0.164 & 47.67 \\
\hline 5 & 0.130 & 47.96 \\
\hline 10 & 0.080 & 48.73 \\
\hline 15 & 0.074 & 48.85 \\
\hline
\end{tabular}



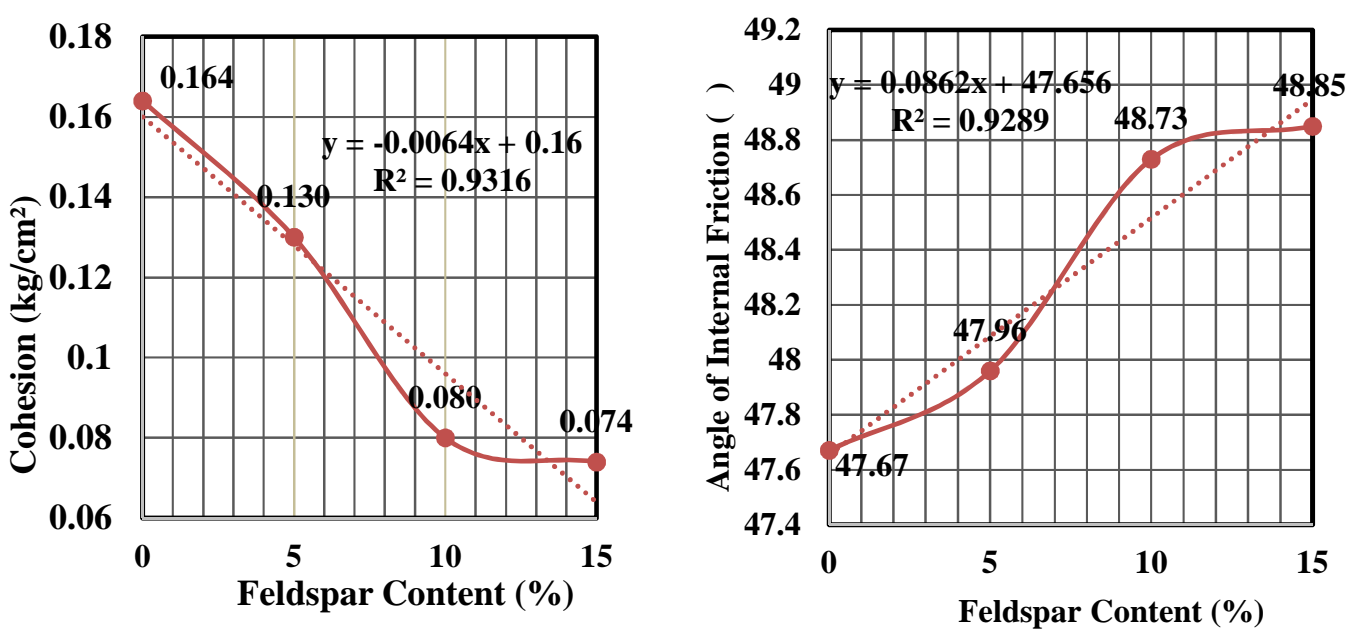

Fig 3.2. Regression model for cohesion (left) and angle of internal friction (right) of aggregate base and subbase

\section{Conclusion}

From overall test results and discussion then conclusions can be drawn as follows:

1. Analyzed using regression models, for CBR and Direct Shear test results, have a coefisien of determination R-square and coefficient of correlation $\mathrm{R}$ above $90 \%$. This means the feldspar has a strong influence in improving the strenght of aggregate base and subbase.

2. Cohesion value after adding with Feldspar become zero, and angle of internal friction $\varphi$ is significantly large, this means that the strenght of aggregate base and also subbase increases.

\section{Acknowledgements}

My special thanks are addressed first to the Institute for Research and Community Service Universitas Islam Sultan Agung (UNISSULA) to financially support this research. Secondly my gratitude is extended to Mrs. Lisa Fitriyana, Ajmil Nabila, and Indah Ulya Rosita, as well as staff in Soil Mechanic laboratory Faculty of Engineering UNISSULA, with their help of this research can be carried out.

\section{References}

[1] Gatot Rusbintardjo (2011). Bitumen Modification Using Oil Palm Fruit Ash for Stone Mastic Asphlat. Ph.D, Thesis - Universiti Teknologi Malaysia.

[2] https://www.civilengineeringterms.com > pavement-and-foundation > base and subbse course. Acces on October 25, 2019

[3] https://www.google.com/search?q=feldspar\&oq=feldspar\&aqs=chrome.0.69i59j69i6013j0 12.5583j0j7\&sourceid=chrome\&ie=UTF-8. Acces on October 25, 2019

[4] Yoder E. J., Witczak M. W. 1975. Principles of Pavement Design. Second Edition. Canada. Pp 300

[5] Robert D Krebs, Richard Walker (1971) HighwayMaterials. McGraw-Hill Book Company-USA. pp. 2

[6] Richard L. Cheaffer and James T. McClave (1990). Probability and Statistics for Engineers. PWS-Kent Publishing Company, Boston USA.

[7] Lambe, T.W. (1951). Soil Testing for Engineers. John Willey and Sons, New York. 